\title{
Cheesemaking properties of a new dairy-based powder made by a combination of microfiltration and ultrafiltration
}

\author{
Anita GAREM*, Pierre Schuck, Jean-Louis MAUBOIS \\ Laboratoire de recherches de technologie laitière, \\ INRA, 65 route de Saint-Brieuc, 35042 Rennes Cedex, France
}

\begin{abstract}
Partial removal of whey protein before heat-treatment, by a combination of membrane microfiltration and ultrafiltration according to an Inra patented process, was expected to avoid the formation of the $\beta$-lactoglobulin- $\kappa$-casein complex during thermal processing and thus to allow the production of a milk powder with cheesemaking abilities similar to those of raw milk. The principles of the process, the characteristics of the resulting new milk powder, and the manufacture of Mozzarella cheese from milk prepared by recombination of this powder were studied with special emphasis on rennet coagulability, melting properties and improvements observed on cheese yielding capacity. Mozarella produced by recombination had same composition and properties as control Mozarella (produced with raw fresh milk), but when the powder was used, the cheesemaking yields were $7.3 \pm 1.8 \%$ higher in comparison with the control cheese. The recovery in total solids, fat and total nitrogen contents showed similar trends. Therefore, such a process may give rise to a new generation of milk powders, especially suitable for cheesemaking in countries suffering a shortage in milk supply.
\end{abstract}

milk powder / microfiltration / ultrafiltration / Mozarella / cheesemaking

\section{INTRODUCTION}

Either because milk production is strongly affected by seasonality or because local milk production is insufficient, approximately 1 million tons of milk powder are used in the world annually for making cheese. Fermented milk products such as yoghurt and fresh cheeses can readily be manufactured from recombined milk, but it is more difficult to produce hard and semihard cheeses. The most critical factor in the manufacture of cheese from recombined milk is the quality of the milk powder used. Gilles and Lawrence [5] pointed out that a low heating temperature is necessary to

\footnotetext{
* Correspondence and reprints. agarem@ rennes.inra.fr
} 
maintain good rennetability of the recombined milk. Most of the problems in cheesemaking ability of medium and high heat milk powder are due to the cumulative effect of heat treatments applied for microbiological control and thermal efficiency reasons during concentration and drying [4]. The heat treatments are known to induce a number of physico-chemical changes, including the inhibition of rennet hydrolysis of $\kappa$-casein and the increase of the micelle electronegativity due to the formation of $\beta$-lactoglobulin- $\kappa$-casein complexes at the micelle surface $[14,16,17]$. Moreover, they lead to the formation of heat-induced, insoluble calcium phosphate precipitates and a consequent reduction in the concentration of native micellar calcium phosphate on subsequent cooling $[15,16]$. As a result, the higher the heat treatment, the lower the degree of paracasein aggregation/fusion due to higher electrostatic repulsion. Indeed, it has been found that protein matrices of cheeses from such treated milk undergo a relatively low degree of curd fusion, as reflected by the higher interfacial area between the protein and fat phases, and exhibit impaired syneresis properties [6].

Several processing treatments based either on lowering the intensity of the thermal treatment or on adding ionic calcium have been investigated for improving the cheesemaking ability of recombined milk. They all aimed to lower the electronegativity of the micelle when processed thermally. With this objective in view, Quiblier et al. [13] proposed a process consisting of the partial removal of $\beta$-lactoglobulin from skimmilk followed by a low or medium heat treatment and leading to production of a new milk powder with improved cheesemaking abilities compared to those of low heat milk powders. The process, patented by Inra, consists of four successive steps: (i) partial or total removal of whey proteins of the milk by microfiltration (MF) performed on membranes with an average pore diameter ranging between 0.1 and $0.2 \mu \mathrm{m}$, (ii) ultrafiltration of the permeate of micro- filtration with UF membranes having a cutoff threshold around $20 \mathrm{~kg} \cdot \mathrm{mol}^{-1}$, (iii) blending of the microfiltration retentate with the permeate of ultrafiltration, (iv) vacuum evaporation and spray drying (medium heat treatment) of the blend.

In the present work, the effect of preparing milk powder according to the above process on cheesemaking characteristics during manufacture by recombination of Mozarella cheese was studied. The crucial investigation was to determine the cheesemaking ability of recombined milk in terms of rennet coagulability, cheese stretching and melting properties and cheese yielding capacity in comparison to fresh milk since it has been usually found that the stretch characteristics of Mozarella-type cheese were impaired when recombined milks was used [5].

\section{MATERIALS AND METHODS}

\subsection{Fresh milk}

Fresh raw skimmilk and cream (fat content: $20 \% \mathrm{w}: \mathrm{w})$ were obtained from an industrial plant (C.L.E., Montauban-de-Bretagne, France). Fresh milk was standardised (3.2\% fat w:w), pasteurised $\left(72{ }^{\circ} \mathrm{C}-20 \mathrm{~s}\right)$, cooled at $4{ }^{\circ} \mathrm{C}$ and kept at this temperature.

\subsection{Skim milk powder}

The skim milk powder was prepared according to the process described earlier and represented in Figure 1 [13]. Microfitration was realised on a MFS19 unit (Tetra Laval, Aarhus, Denmark) equipped with $4.6 \mathrm{~m}^{2}$ of Membralox $0.1 \mu \mathrm{m}$ membranes (SCT, Bazet, France). Temperature and permeate flux were $50{ }^{\circ} \mathrm{C}$ and $75 \mathrm{~L} \cdot \mathrm{h}^{-1} \cdot \mathrm{m}^{-2}$, respectively.

Ultrafiltration was carried out on a DDS module (GEA, Soeborg, Denmark) with $9 \mathrm{~m}^{2}$ of flat membranes having a nominal cut-off threshold of $20 \mathrm{~kg} \cdot \mathrm{mol}^{-1}$. 


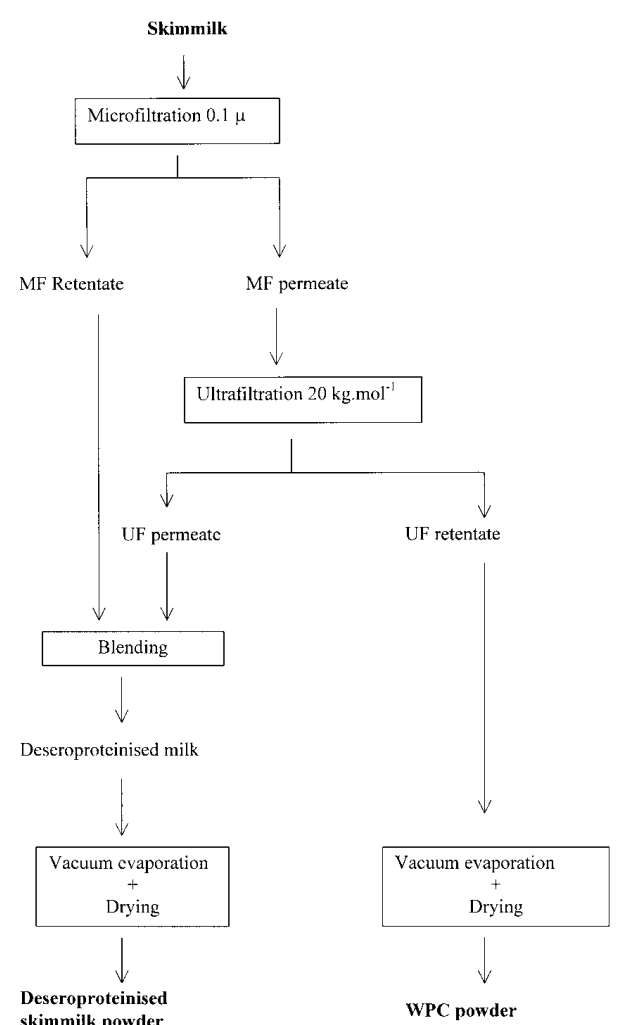

Figure 1. Schematic description of the process of preparation of the whey protein depleted skimmilk powder.

Temperature and permeate flux were $50{ }^{\circ} \mathrm{C}$ and $40 \mathrm{~L} \cdot \mathrm{h}^{-1} \cdot \mathrm{m}^{-2}$, respectively.

Microfiltration retentate and ultrafiltration permeate were blended at room temperature. The mixture was concentrated in a two-stage falling film vacuum evaporation plant (GEA, St-Quentin en-Yvelines, France) at Bionov (Rennes, France). The first evaporation stage was carried out at $71 \pm 2{ }^{\circ} \mathrm{C}$ and led to a concentrated milk temperature of $47 \pm 2{ }^{\circ} \mathrm{C}$. Evaporation capacity of water was $180 \mathrm{~kg} \cdot \mathrm{h}^{-1}$. Spray drying of the concentrated milk was realized at Bionov (Rennes, France), in a three-stage pilot plant spray dryer, (GEA, St-Quentin-en-Yvelines, France). This atomizer was equipped with a pressure nozzle ( $0.73 \mathrm{~mm}$ orifice diameter) and a 4-slot core ( $0.51 \mathrm{~mm}$ nominal width), leading to a $60^{\circ}$ sprayer angle. The evaporation capacity of water was 70 to $120 \mathrm{~kg} \cdot \mathrm{h}^{-1}$. The pressure nozzle was at $16 \mathrm{MPa}$. Inlet air temperature was $250 \pm 2{ }^{\circ} \mathrm{C}$, integrated fluid bed air temperature was $76 \pm 2{ }^{\circ} \mathrm{C}$, and outlet air temperature was $88 \pm 3{ }^{\circ} \mathrm{C}$.

At the end of the process, $1000 \mathrm{~L}$ of fresh skimmilk resulted in $87.7 \mathrm{~kg}$ of milk powder (total solids (TS): $960 \mathrm{~g} \cdot \mathrm{kg}^{-1}$, total nitrogen (TN)/TS: $33.7 \%$, caseins/TN: $81.5 \%$, whey protein/TN: $11 \%)$. The by-product was a whey protein concentrate powder (4 kg with TS: $95 \%$ and TN/TS: $77 \%$ ).

\subsection{Recombined milk}

Reconstituted skimmilk was prepared by mixing skimmilk powder $(9.6 \% \mathrm{w}$ : w of the total reconstituted skimmilk) with water at $40{ }^{\circ} \mathrm{C}$. The mix was then standardised to $3.2 \%$ fat (w:w) with the cream, pasteurised $\left(72{ }^{\circ} \mathrm{C}-20 \mathrm{~s}\right)$, cooled at $4{ }^{\circ} \mathrm{C}$ and kept at this temperature.

\subsection{Cheese manufacture}

A series of Mozarella cheeses (2 replicates) were made from fresh milk (control) and recombined milk (RM) according to the protocol below.

At $35^{\circ} \mathrm{C}$, starter cultures were added to the milk. The starter cultures consisted in the following micro-organisms (for $10 \mathrm{~kg}$ ): $100 \mathrm{~g}$ of Lactobacillus helveticus (Texel, Dangé Saint-Romain, France), $100 \mathrm{~g}$ of Streptococcus salivarius ssp. thermophilus (Texel, Dangé Saint-Romain, France), $10 \mathrm{~g}$ of Lactococcus lactis ssp. lactis var. diacetyl (Texel, Dangé St-Romain, France). Also, $1 \mathrm{~g}$ of $\mathrm{CaCl}_{2}$ was added to the milk. The pre-acidification of the milk was carried out at $36{ }^{\circ} \mathrm{C}$ for $1 \mathrm{~h}$. Then, $2 \mathrm{~mL}$ of rennet extract $\left(520 \mathrm{mg} \cdot \mathrm{L}^{-1}\right.$ chymosin, Granday, France) were added to each $10 \mathrm{~kg}$ batch. Coagulation time was $30 \mathrm{~min}$ for RM and control. 
As usual, curds were cut to corn grain size pieces and, after $5 \mathrm{~min}$ at $35^{\circ} \mathrm{C}$, the curd/whey mixture was heated to $41^{\circ} \mathrm{C}$ for 15 min with only periodic gentle agitation.

After further $20 \mathrm{~min}$, the free whey was drained and curds were packed gently together towards the back of the vat and then trenched and pressed to speed the draining.

The $\mathrm{pH}$ of the whey, the titratable acidity and the drained volume were continuously measured. At the end of the draining, samples of the total whey collected were taken for physico-chemical analysis.

Similarly, the $\mathrm{pH}$ of the curds was continuously measured. When it was close to 5.1 , the curd blocks were quickly vacuum packaged and set into an ice bath to stop the acidification. The cheeses were stored at $4{ }^{\circ} \mathrm{C}$. Samples for analysis were taken the day after.

\subsection{Cheese stretching and molding}

After $24 \mathrm{~h}$ of storage at $4{ }^{\circ} \mathrm{C}$, curds, in $250 \mathrm{~g}$ packs, were heated in $62^{\circ} \mathrm{C}$ water for $10 \mathrm{~min}$. The resulting paste-like texture was stretched manually 4 or 5 times and placed in molds ( $9 \mathrm{~cm}$ diameter, $5 \mathrm{~cm}$ height). Then the cheese was rinsed and cooled in running cold water for $30 \mathrm{~min}$, smoothly dried and pickled at $10{ }^{\circ} \mathrm{C}$ for $135 \mathrm{~min}$ before vacuum packaging. The packaged cheese was stored at $4{ }^{\circ} \mathrm{C}$. The melting tests were realised 6 days after stretching.

\subsection{Analytical measurements}

The total solids (TS) content was determined by weight loss after drying $5 \mathrm{~g}$ sample mixed with sand in a forced air oven at $105^{\circ} \mathrm{C}$ for $7 \mathrm{~h}$ [7]. Fat content was determined by using acido-butyrometric method of Gerber [2]. Ash contents were determined by incineration of $10 \mathrm{~mL}$ sample in the muffle furnace at $530{ }^{\circ} \mathrm{C}$ for $4 \mathrm{~h}$. Total nitrogen
(TN), non casein nitrogen ( $\mathrm{NCN}$ ) and non protein nitrogen (NPN) were determined by the Kjeldahl procedure [8]. After appropriate dilutions, the total calcium content was quantified by atomic absorption spectrometry on a Varian AA 300 equipment (Sunnyvale, USA), according to the method described in Brulé et al. [3]. Chloride content was determined directly on a Corning Model 926 equipment (Humeau, La Chapelle, France). Lactose was determined according to Acton [1]. Mass balances were systematically calculated for every cheese to control yields and recoveries of each cheese constituent. Yields and recoveries were corrected according to Maubois and Mocquot [11].

Rennet coagulability was estimated with a Formagraph equipment (Foss Electric Nanterre, France) through the measurement of three parameters: rennet clotting time R, the time to achieve $20 \mathrm{~mm}$ firmness (K20), the gel firmness at twice the clotting time (Ar). Melting tests were realised on cheese discs (31 $\mathrm{mm}$ diameter, $5 \mathrm{~mm}$ thickness) that were heated at $230{ }^{\circ} \mathrm{C}$ for $5 \mathrm{~min}$. The melting coefficient was the multiplication coefficient between the surface before heating and the surface after heating.

\section{RESULTS AND DISCUSSION}

\subsection{Composition of the milk}

As expected, the milk obtained by recombination (RM) was enriched in casein relative to the total nitrogen $(+7.6 \%)$ and depleted of whey protein relative to the total nitrogen $(-31 \%)$ in comparison to the fresh milk (control) (Tab. I). Amounts of other components were not significantly different except for the ratio Calcium/TN that was $10 \%$ higher for the RM (Tab. I). This could be related to the larger amount of casein in $\mathrm{RM}$ since under these conditions of $\mathrm{pH}$ and temperature, about $66 \%$ of the milk calcium forms complexes with the casein [9]. 
Table I. Compositions $\left(\mathrm{g} \cdot \mathrm{kg}^{-1}\right)$ and $\mathrm{pH}$ of cheesemaking milk. RM: recombined milk, Control: fresh milk, TS: total solids content, TN: total nitrogen content, NCN: non casein nitrogen content, NPN: non protein nitrogen content, WP: whey proteins, $\mathrm{Ca} / \mathrm{TN}$ : ratio calcium content on total nitrogen, $\sigma$ : standard deviation calculated from 2 repetitions.

\begin{tabular}{lccccccccccc}
\hline & PH & TS & Fat & TN & NCN & NPN Casein & WP & Ash & $\begin{array}{c}\mathrm{Ca} / \mathrm{TN} \\
\%\end{array}$ \\
\cline { 2 - 8 } & \multicolumn{8}{c}{} & \multicolumn{7}{c}{$\mathrm{g} \cdot \mathrm{kg}^{-1}$} \\
\hline $\mathrm{RM}$ & 6.75 & 119.70 & 30.40 & 32.20 & 5.20 & 1.70 & 27.0 & 3.2 & 7.90 & 4.04 \\
$\sigma$ & 0.03 & 0.90 & 1.00 & 1.00 & 0.10 & 0.00 & 0.63 & 0.10 & 0.00 & 0.10 \\
Control & 6.73 & 117.60 & 30.50 & 33.10 & 7.40 & 2.10 & 25.7 & 5.3 & 7.40 & 3.62 \\
$\sigma$ & 0.03 & 2.50 & 1.50 & 0.65 & 0.10 & 0.10 & 0.70 & 0.20 & 0.00 & 0.30 \\
\hline
\end{tabular}

\subsection{Rennet coagulability}

$\mathrm{R}$ and $\mathrm{K} 20$ were similar for RM and the control milk in spite of the difference in the amount of whey proteins (Tab. II). Likewise, the kinetics of acidification were not significantly different for RM versus control (results non shown). This contradicts expectations from the literature, as the presence of whey proteins is often considered to be detrimental for the casein aggregation $[14,15]$. However, a clear difference was observed in relation to the firmness of the gels, which was much higher for the RM, undoubtedly due to the higher casein/TN ratio for the RM (Tab. II). Moreover the whey proteins are known to entrap water and so, to confer a softened texture to the coagulum, notably when they are concentrated by ultrafiltration in the cheesemaking milk. This was described in detail in several studies on cheeses made from UFconcentrated milk $[10,12]$. Therefore, it is reasonable to assume that, in the present work, the specific decrease of whey protein content of the milk lead to firmer gels.

\subsection{Physico-chemical composition of drained curd and whey}

Differences in the composition between the RM and the control curds were mainly observed for the amount of nitrogenous
Table II. Rennet coagulability of cheesemaking milk (formagraph analysis at $30^{\circ} \mathrm{C}, \mathrm{pH} 6.6$ ). RM: recombined milk, Control: fresh milk, $\mathrm{R}$ : rennet clotting time ( $\mathrm{min}), \mathrm{K} 20$ : time to achieve $20 \mathrm{~mm}$ firmness (min), Ar: gel firmness at twice the clotting time $(\mathrm{mm})$.

\begin{tabular}{lccc}
\hline & $\begin{array}{c}\mathrm{R} \\
\mathrm{min}\end{array}$ & $\begin{array}{c}\mathrm{K} 20 \\
\mathrm{~min}\end{array}$ & $\begin{array}{c}\mathrm{Ar} \\
\mathrm{mm}\end{array}$ \\
\hline $\mathrm{RM}$ & 21.0 & 10.0 & 29.0 \\
Control & 21.5 & 10.5 & 22.0 \\
\hline
\end{tabular}

components (Tab. III). However, in contrast to that observed for the milk, the casein/TN ratio was not very different for the curds (Casein/TN: $94.7 \%$ for the control, versus $95 \%$ for the RM curds; $78 \%$ versus $84 \%$ respectively the two milk batches) (Tab. III). This could be related to the fact that when amounts of casein in RM and control curds are similar (Tab. III), the difference in non casein nitrogen $(\mathrm{NCN})$ has decreased by half in curds in comparison to the milk (NCN: $12.28 \mathrm{~g} \cdot \mathrm{kg}^{-1}$ for the control, versus $10.50 \mathrm{~g} \cdot \mathrm{kg}^{-1}$ for the RM curds; (the difference between both equals $14.5 \%$ ) and $7.40 \mathrm{~g} \cdot \mathrm{kg}^{-1}$ versus $5.20 \mathrm{~g} \cdot \mathrm{kg}^{-1}$ respectively in the milk (the difference between both then equals 30\%) (Tab. III). Moreover, casein and whey protein contents in the resulting wheys were $32 \%$ and $35 \%$, 
Table III. Compositions $\left(\mathrm{g} \cdot \mathrm{kg}^{-1}\right)$ of drained curds and wheys. RM: recombined milk, Control: fresh milk, TS: total solids content, TN: total nitrogen content, NCN: non casein nitrogen content, NPN: non protein nitrogen content, Ca: calcium content, $\sigma$ : standard deviation calculated from 2 repetitions.

\begin{tabular}{lcccccccc}
\hline & TS & Fat & TN & Casein & NCN & NPN & Ash & Ca \\
\cline { 2 - 9 } & & & \multicolumn{7}{c}{$\mathrm{g} \cdot \mathrm{kg}^{-1}$} \\
RM & & & & & & & \\
Curd & 517.20 & 240.09 & 232.71 & 221.21 & 10.50 & 5.14 & 24.46 & 7.52 \\
$\sigma$ & 2.05 & 6.19 & 0.65 & 0.74 & 0.09 & 0.18 & 0.06 & 0.04 \\
Whey & 64.77 & 2.37 & 6.66 & 0.47 & 6.19 & 2.38 & 5.77 & 0.46 \\
$\sigma$ & 0.33 & 0.68 & 0.20 & 0.24 & 0.04 & 0.02 & 0.05 & 0.01 \\
Control & & & & & & & & \\
Curd & 516.96 & 241.86 & 231.87 & 219.59 & 12.28 & 5.72 & 23.63 & 7.37 \\
$\sigma$ & 5.53 & 5.40 & 1.23 & 2.53 & 1.30 & 0.50 & 0.71 & 0.28 \\
Whey & 66.68 & 4.00 & 9.02 & 0.73 & 8.29 & 2.72 & 5.48 & 0.40 \\
$\sigma$ & 1.36 & 1.56 & 0.07 & 0.20 & 0.13 & 0.11 & 0.01 & 0.02 \\
\hline
\end{tabular}

respectively lower for the RM compared with the control (Tab. III). This may be related to the assumption raised before, regarding the depletion of whey protein in RM which would have produced firmer coagulums that could have better ability to trap the protein during syneresis.

\subsection{Properties of Mozarella cheeses and estimation of component losses during stretching}

As expected from the above results concerning the curds, the composition (Tab. IV) and the melting properties (result non shown) of the final Mozarella cheeses were nearly identical for RM and control. However, the casein and the whey protein contents of stretch waters were around $25 \%$ lower for the RM cheese as compared to the control (Tab. IV). The loss of milk components was significantly lower for the RM cheeses, probably because they might have been more strongly trapped in the tighter cheese matrix of RM.

Finally, the cheesemaking yields and gross recoveries of milk total solids, fat and total nitrogen have been compared for Mozarella fabrications with RM and control milk (Tab. V). The crucial point of this determination is that when RM was used, cheesemaking yields were $7.3 \pm 1.8 \%$ higher in comparison with the control cheese. Similarly, TS, fat and TN recovery values were $5.1 \pm 2 \%, 6.7 \pm 1 \%$ and $2.5 \pm 1 \%$ higher for $\mathrm{RM}$ in comparison to the control. Therefore, the results presented here, not only confirm the Mozarella cheesemaking ability of the recombined milk, but also indicate that the use of the recombined milk was advantageous compared to fresh milk, in terms of yields and milk component recovery, confirming experimentally the claims of Quiblier et al. [13]. Contrary to common recombined milk, it was not necessary to modify the cheesemaking procedure [5].

\section{CONCLUSION}

Mozarella cheese may be made successfully from recombined milk using milk powders specifically enriched in casein and partially depleted of whey proteins by a combination of microfiltration and 
Table IV. Compositions $\left(\mathrm{g} \cdot \mathrm{kg}^{-1}\right)$ and $\mathrm{pH}$ of Mozarella cheeses and stretch water. RM: recombined milk, Control: fresh milk, TS: total solids content, TN: total nitrogen content, NCN: non casein nitrogen content, NPN: non protein nitrogen content, Ca: calcium content, $\sigma$ : standard deviation calculated from 2 repetitions.

\begin{tabular}{lccccccccc}
\hline & $\mathrm{pH}$ & $\mathrm{TS}$ & $\mathrm{Fat}$ & $\mathrm{TN}$ & $\mathrm{NCN}$ & $\mathrm{NPN}$ & Ash & $\mathrm{NaCl}$ & $\mathrm{Ca}$ \\
\cline { 2 - 9 } & & & & \multicolumn{7}{c}{$\mathrm{g} \cdot \mathrm{kg}^{-1}$} & & & & \\
\hline RM & & & & & & & & & \\
Mozarella & 5.40 & 537.36 & 246.03 & 235.79 & 13.07 & 5.04 & 32.82 & 13.58 & 7.21 \\
$\sigma$ & 0.07 & 0.02 & 0.05 & 0.00 & 0.03 & 0.18 & 1.05 & 0.01 & 0.01 \\
Stretch water & 4.92 & 22.35 & 5.98 & 3.10 & 2.46 & 1.36 & 4.67 & nd & 1.29 \\
$\sigma$ & 0.05 & 0.97 & 2.49 & 0.86 & 0.85 & 0.32 & 0.65 & nd & 0.16 \\
& & & & & & & & & \\
Control & & & & & & & & & \\
Mozarella & 5.40 & 534.75 & 245.55 & 236.83 & 12.18 & 5.23 & 31.09 & 12.26 & 6.98 \\
$\sigma$ & 0.02 & 0.65 & 0.75 & 0.01 & 0.95 & 0.23 & 0.45 & 0.47 & 0.32 \\
Stretch water & 4.91 & 22.50 & 5.00 & 3.50 & 2.71 & 1.39 & 4.56 & nd & 1.23 \\
$\sigma$ & 0.05 & 0.90 & 2.00 & 0.66 & 0.74 & 0.30 & 0.70 & nd & 0.19 \\
\hline
\end{tabular}

nd: not determined.

Table V. Cheese yields (\%) and gross recoveries of TS, fat and TN (\%). RM: recombined milk, Control: fresh milk, TS: total solids content, TN: total nitrogen content, $\sigma$ : standard deviation calculated from 2 repetitions. Calculations adjusted for cheese with 50\% TS.

\begin{tabular}{lcccc}
\hline & $\begin{array}{c}\text { Weight } \\
(\mathrm{kg})\end{array}$ & \multicolumn{3}{c}{ Recovery $(\%)$} \\
\cline { 3 - 4 } & & $\mathrm{TS}$ & Fat & $\mathrm{TN}$ \\
\hline $\mathrm{RM}$ & & & \\
milk & 100 & 100 & 100 & 100 \\
Whey & 87.34 & 47.09 & 3.66 & 18.23 \\
$\sigma$ & 0.29 & 0.74 & 0.20 & 0.03 \\
Mozarella & 12.66 & 52.91 & 96.34 & 81.77 \\
$\sigma$ & 0.25 & 0.50 & 0.50 & 0.40 \\
Control & & & & \\
milk & 100 & 100 & 100 & 100 \\
Whey & 88.20 & 49.81 & 9.76 & 20.23 \\
$\sigma$ & 0.60 & 0.50 & 0.50 & 0.40 \\
Mozarella & 11.80 & 50.19 & 90.24 & 79.77 \\
$\sigma$ & 0.15 & 0.55 & 0.36 & 0.45 \\
\hline
\end{tabular}

ultrafiltration. The process leads to a significant cheese yield increase $(+7.3 \%)$ as well as an important decrease in whey and stretch water losses. Moreover, its utilisation does not require the addition of chemical additives or any adaptation of the cheesemaking parameters. In parallel, similar studies have been carried out on manufacturing different soft, semi hard and hard cheeses from cow's, goat's or ewe's milk. Yield and protein gross recovery were always at least $5 \%$ and $4 \%$ higher for 
recombined milk than for fresh milk. Therefore, such a process may give rise to a new generation of milk powders, especially suitable for cheesemaking in countries suffering a shortage in milk supply.

\section{REFERENCES}

[1] Acton G.H., The determination of lactose in cheese, Austr. J. Dairy Technol. 32 (1977) 111-117.

[2] AFNOR, Norme NF V 04-210, Détermination de la teneur en matière grasse par la méthode acido-butyrométrique (1990).

[3] Brulé G., Maubois J.L., Fauquant J., Étude de la teneur en éléments minéraux des produits obtenus lors de l'ultrafiltration du lait sur membrane, Lait 54 (1974) 600-615.

[4] Ferron-Baumy C., Maubois J.L., Garric G., Quiblier J.P., Coagulation présure du lait et des rétentats d'ultrafiltration : effets de divers traitements thermiques, Lait 71 (1991) 423-434.

[5] Gilles J., Lawrence R.C., The manufacture of cheese and other fermented products from recombined milk, N. Z. J. Dairy Sci. Technol. 16 (1981) 1-12.

[6] Guinnee T.P., Pudja P.D., Reville W.J., Harrington D., Mulholland E.O., Cotter M., Cogan T.M., Composition, microstructure and maturation of semi-hard cheeses from high protein ultrafiltrated milk retentates with different levels of denatured proteins. Int. Dairy J. 5 (1995) 543-568.

[7] IDF Dry matter and ash. Standard 21, International Dairy Federation, Brussels (1971).

[8] IDF Détermination de la teneur en azote. Standard 20B, International Dairy Fédération, Brussels (1993).
[9] Le Graet Y., Brulé G., Effets de la concentration par évaporation et du séchage sur les équilibres minéraux du lait et les rétentats. Lait 62 (1982) 113-125.

[10] Mahaut M., Korolczuck J., Effect of whey protein addition and heat treatment of milk on the viscosity of UF fresh Cheeses, Milchwissenschaft 47 (1992) 157-168.

11] Maubois J.L., Mocquot G., Comment ramener à la même teneur en substance sèche des fabrications de fromages en vue de comparer les rendements respectifs du lait en fromage ?, R.L.F. 239 (1967) 15-18.

[12] Maubois J.L., Mocquot G., Préparation de fromage à partir de «préfromage liquide » obtenu par ultrafiltration du lait, Lait 71 (1971) 495-533.

[13] Quiblier J.P., Ferron-Baumy C., Garric G., Maubois J.L., Procédé de traitement des laits permettant au moins de conserver leur aptitude fromagère, Brevet Français $\mathrm{n}^{\circ} 0542583$ B 1 (1992).

[14] Reddy I.M., Kinsella J.E., Interaction of $\beta$-lactoglobulin with $\kappa$-casein in micelles as assessed by chymosin hydrolysis: effect of temperature, heating time, $\beta$-lactoglobulin concentration and pH, J. Agric. Food Chem. 38 (1990) 50-58.

[15] Singh H., Shalabi S.I., Fox P.F., Flynn A., Barry A., Rennet coagulation of heated milk: the influence of $\mathrm{pH}$ adjustment before and after heating, J. Dairy Res. 49 (1988) 153-157.

[16] van Hooydonk A.C.M., de Koester P.G., Boerringter I.J., The renneting of heated milk, Neth. Milk. Dairy J. 41 (1987) 3-18.

[17] Wheelock J.V., Kirck A., The role of $\beta$-lactoglobulin in the primary phase of rennin action on heated casein micelles and heated milk, J. Dairy Res. 41 (1974) 367-372.

For all information regarding economic or commercial aspect of operating Patent $\mathrm{N}^{\circ}$ 924026133, please contact Mr Jules-Henri Prime, INRA licensee and authorized representative by postmail at the following address: 71 rue de la Bastille, 44000 Nantes, France; or by fax: 33 (0) 240892903. 